\title{
Lowland extirpation of anuran populations on a tropical mountain
}

\author{
Marconi Campos Cerqueira Junior ${ }^{\text {Corresp., }}{ }^{1}$, T. Mitchell Aide ${ }^{1}$ \\ 1 University of Puerto Rico-Rio Piedras, San Juan, Puerto Rico \\ Corresponding Author: Marconi Campos Cerqueira Junior \\ Email address: marconi.campos.cerqueira@gmail.com
}

Background. Climate change and infectious diseases threaten animal and plant species, even in natural and protected areas. To cope with these changes, species may acclimate, adapt, move or decline. Here, we test for shifts in anuran distributions in the Luquillo Mountains (LM), a tropical montane forest in Puerto Rico by comparing species distributions from historical (1931-1989) and current data (2015/2016).

Methods. Historical data, which included different methodologies, were gathered through the Global Biodiversity Information Facility (GBIF) and published literature, and the current data were collected using acoustic recorders along three elevational transects.

Results. In the recordings, we detected the 12 native frog species known to occur in LM. Over a span of $\sim 25$ years, two species have become extinct and four species suffered extirpation in lowland areas. As a consequence, low elevation areas in the LM $(<300 \mathrm{~m})$ have lost at least six anuran species.

Discussion. We hypothesize that these extirpations are due to the effects of climate change and infectious diseases, which are restricting many species to higher elevations and a much smaller area. Land use change is not responsible for these changes because LM has been a protected reserve for the past 80 years. However, previous studies indicate that 1 ) climate change has increased temperatures in Puerto Rico, and 2) Batrachochytrium dendrobatidis (Bd) was found in 10 native species and early detection of $\mathrm{Bd}$ coincides with anurans declines in the LM. Our study confirms the general impressions of amphibian population extirpations at low elevations, and corroborates the levels of threat assigned by IUCN. 
1 Lowland extirpation of anuran populations on a tropical mountain.

2

3 Marconi Campos-Cerqueira $^{1}$ and T. Mitchell Aide ${ }^{1}$

4

$5{ }^{1}$ University of Puerto Rico-Rio Piedras, San Juan, Puerto Rico 00931-3360

6

7 Corresponding author: Marconi Campos Cerqueira

8

9 Email address: marconi.campos.cerqueira@gmail.com

10

11

12

13

14

15

16

17

18

19

20

21

22

23

24

25

26

27

28

29

30

31

32

33

34

35

36

37

38

39

40 
41 Abstract

42

Background. Climate change and infectious diseases threaten animal and plant species, even in natural and protected areas. To cope with these changes, species may acclimate, adapt, move or decline. Here, we test for shifts in anuran distributions in the Luquillo Mountains (LM), a tropical montane forest in Puerto Rico by comparing species distributions from historical (19311989) and current data (2015/2016).

Methods. Historical data, which included different methodologies, were gathered through the Global Biodiversity Information Facility (GBIF) and published literature, and the current data were collected using acoustic recorders along three elevational transects.

Results. In the recordings, we detected the 12 native frog species known to occur in LM. Over a span of $\sim 25$ years, two species have become extinct and four species suffered extirpation in lowland areas. As a consequence, low elevation areas in the LM $(<300 \mathrm{~m})$ have lost at least six anuran species.

Discussion. We hypothesize that these extirpations are due to the effects of climate change and infectious diseases, which are restricting many species to higher elevations and a much smaller area. Land use change is not responsible for these changes because LM has been a protected reserve for the past 80 years. However, previous studies indicate that 1) climate change has increased temperatures in Puerto Rico, and 2) Batrachochytrium dendrobatidis (Bd) was found in 10 native species and early detection of Bd coincides with anurans declines in the LM. Our study confirms the general impressions of amphibian population extirpations at low elevations, and corroborates the levels of threat assigned by IUCN.

64

65

66

67

68

69

70

71

72

73

74

75

76

77

78

79

80

81

82

83

84

85

86 


\section{Introduction}

88

89

90

91

92

93

94

95

96

97

98

99

100

101

102

103

104

105

106

107

108

109

110

111

112

113

114

115

116

117

118

119

120

121

122

123

124

125

126

The $21^{\text {th }}$ century marks an era in which biodiversity is threatened at the global scale. Although habitat loss and degradation due to human activities are the main threats to animal and plant species around the world (WWF 2016), populations of many species are declining even in natural and protected areas (Hedges 1993; Stuart et al. 2004; Lips et al. 2005; Skerratt et al. 2007; Collins, Crump \& Lovejoy III 2009). To explain these declines in undisturbed habitats, scientists have focused on the widespread effects of climate change and infectious diseases. Climate change is linked to local extinctions and has altered species distributions and abundance, causing an overall shift toward higher latitudes and altitudes (Parmesan 2006; Seimon et al. 2007; Raxworthy et al. 2008; Lenoir et al. 2008; Chen et al. 2011; Ficetola \& Maiorano 2016). Infectious diseases, such as chytridiomycosis, have also caused local extinctions and population declines around the world, especially in cool moist enviroments characteristic of many upland tropical areas (Whitfield, Lips \& Donnelly 2016) altering the spatial distribution of many species (Pounds et al. 2006; Di Rosa et al. 2007; Lips 2016).

Although an increasing number of studies have documented changes in species distributions in tropical regions (Pounds, Fogden \& Campbell 1999; Raxworthy et al. 2008; Chen et al. 2011; Feeley et al. 2011; Forero-Medina et al. 2011; Harris et al. 2012; CamposCerqueira et al. 2017) the majority of information on range shifts comes from temperate regions, (Lenoir \& Svenning 2014), resulting in large uncertainties in predicting the responses of tropical species to different global changes scnearios (Feeley \& Silman 2011). Nevertheless, a recent study has shown that hundreds of species have already suffered local extinction in the tropics (Wiens 2016). In addition, tropical montane areas are among the most threatened ecosystems due to global warming (Still, Foster \& Schneider 1999; Williams, Jackson \& Kutzbach 2007). The flora and fauna in these areas are expected to suffer the greatest proportion of extinctions due to climate change (Sekercioglu et al. 2008). From a conservation perspective, this is particular troublesome given that tropical montane areas harbor a large portion of the world biodiversity and have high levels of endemism (Gradstein, Homeier \& Gansert 2008).

Amphibians are the taxonomic group with highest number of species critically endangered in the world (IUCN), and some of the most catastrophic declines of amphibian have occurred in tropical forests in Costa Rica (Crump et al. 1992, Pounds \& Crump 1994) and Panama (Lips 1999). In cloud forest near Monteverde, Costa Rica, the golden toad (Incilius periglenes) has been confirmed as extinct, and at least 20 other anuran species were extirpated from this locality, presumably due to regional climate change (Pounds et al. 1999). Many other tropical anurans have suffered local extinctions and changes in their distributions. Amphibian population declines have also been reported in Brazil (Heyer et al. 1988), Puerto Rico (Joglar \& Burrowes 1996), Ecuador (Bustamante et al. 2005), Venezuela (La Marca \& Reinthaler 1991), Central Africa (Hirschfeld et al. 2016), and Australia (Richards et al. 1993; Laurance et al. 1996), and many other species have shifted their distributions to higher elevations (Seimon et al. 2007; Bustamante et al. 2005). The two major culprits for these population declines and changes 
127 in distributions are climate change (Winter et al. 2016) and chytridiomycosis (Lips et al. 2015). 128 Here we address the question: Have there been elevational shifts in anuran distributions within 129 the largest protected area in Puerto Rico? To answer this question, we compared the historical 130 and current elevational distributions of 12 species within the Luquillo Mountains. Specifically, 131 we quantified species distribution (i.e. occupancy) along an elevation gradient $(\sim 0-1,050 \mathrm{~m})$ 132 and tested for shifts in anuran distributions by comparing occupancy probabilities between 133 historical (1931-1989) and current data (2015-2016). Our study provides a quantitative 134 description of elevational shifts in anuran species in a tropical mountain, and a quantitative 135 baseline for future studies of these species.

136

137

138

139

140

141

142

143

144

145

146

147

148

149

150

151

152

153

154

155

156

157

158

159 160

161

162

163

164

165

166

\section{Materials \& Methods}

\section{Study site}

The study was conducted in the Luquillo Mountains (LM) in north-eastern Puerto Rico (Figure 1). The majority of LM is protected by the El Yunque National Forest (EYNF), also known as the Luquillo Experimental Forest, which is the largest protected area $\left(115 \mathrm{~km}^{2}\right)$ of primary forest in Puerto Rico (Lugo 1994). The LM spans an elevational range from 100 to 1074 $\mathrm{m}$ and its highest peak is only $8 \mathrm{~km}$ from the ocean, creating a steep elevation gradient. This protected site is ideal for testing for elevational shifts for three reasons: 1) There have been no direct effects of land use change during the last 80 years in the LM; 2) The LM comprises three main peaks (Pico del Este - 1051 m, Pico del Yunque -1050 m, Pico del Toro - 1074 m) allowing the establishment of several elevational gradients; and 3) There has been extensive research documenting abiotic and biotic changes along the elevational gradient. For instance, the LM elevational gradient has a positive relationship with rainfall, runoff, humidity, cloud cover and wind velocity (Briscoe 1966; García-Martinó et al., 1996; Weaver \& Gould 2013) and a negative relationship with temperature, forest growth, and canopy height (Weaver \& Murphy 1990; Weaver 2000; Wang et al. 2003; Weaver \& Gould 2013). Temperature declines with elevation from $\sim 26.5^{\circ} \mathrm{C}$ in the lowlands to $\sim 20^{\circ} \mathrm{C}$ at the mountain top (Waide et al. 2013). Annual rainfall ranges from $2450 \mathrm{~mm}$ yr-1at lower elevations to over $4000 \mathrm{~mm}$ yr-1at higher elevations (Waide et al. 2013). In addition, the distribution of plants and animals are also affected by this elevation gradient (Gould, Gonzalez \& Rivera 2006; González et al. 2007; Gould et al. 2008; Willig et al. 2011; Brokaw et al. 2012; Weaver \& Gould 2013; Campos-Cerqueira \& Aide 2016).

\section{Species}

The anuran community in the LM includes 13 native species of tree frogs commonly referred to "coquis" (Eleutherodactylus spp.) and one native frog species from the Leptodactylidae family (Table 1). The coquis are terrestrial-breeding, direct-development species, and calling and reproductive activity occurs year-round (Stewart \& Pough 1983; 
167 Woolbright 1985; Stewart 1995; Joglar 1998). All coqui species are very active throughout the

168

169

170

171

172

173

174

175

176

177

178

179

180

181

182

183

184

185

186

187

188

189

190

191

192

193

194

195

196

197

198

199

200

201

202

203

204

night and most species have a peak of vocal activity around 20:00 (Villanueva-Rivera 2014). Eleutherodactylus coqui is one of the most studied species in Puerto Rico. Both males and females are strongly territorial, and they rarely move more than five meters from their retreat sites (Woolbright 1985; Woolbright 1996; Joglar 1998). Ten of the 13 species tree frogs are endemics to Puerto Rico/Puerto Rican bank and eight are listed in the IUCN Red List (Table 1).

\section{Historical data}

The historical data was acquired through the compilation of all available information about the species distributions in published and open sources (Table S1, Table S2, TableS3). While some data sets provided quantitative information about the presence of the species associated with a specific georeferenced location (e.g. GBIF 2016, Joglar 1998; Drewry \& Rand 1983), others data sets (e.g. Schwartz \& Henderson 1991; Rivero 1998) provided qualitative information about species distribution range that was used to support the quantitative data. The information about species distribution from the historical data sets were acquired using different sampling methods, from opportunistic observations to mark-recapture and acoustic monitoring. Rather than being a drawback, the use of these complementary methods may increase species detectability. As far as we know, our compilation is the most comprehensive collection of historical data on anuran distributions in the Luquillo Mountains in Puerto Rico.

For a record to be included in our quantitative historical data set, it had to fulfill three criteria: 1) the record had to include a georeferenced locality or a specific geographical description that enabled us to georeference the locality; 2) the record had to be within the LM area; and 3) the record had to be before 1990. We used records before 1990 because this date coincides with the decline of many populations of coqui species in the LM (Burrowes, Joglar \& Green 2004), and create a gap of $\sim 25$ years between the historical and current data sets. All geographical coordinates from the Global Biodiversity Information Facility (GBIF) data set were checked and corrected (Table S2).

\section{Current data}

We collected acoustic data from 67 sites in the LM along three elevational transects (84$1049 \mathrm{~m}$ ) between March and May of 2015 and again in April and May of 2016. The survey was conduct in the months of March, April, and May because this is the period of greatest vocal activity for the majority of anuran species (Joglar 1998). The elevational transect took advantage of roads and trails, but all audio recorders were placed more than $200 \mathrm{~m}$ from any road. Each elevational transects started in the lowlands and reached one of the three main mountain peaks of the Luquillo mountains (East Peak, Toro Peak, El Yunque Peak). Along each elevational transect, two audio recorders, separated at least by $200 \mathrm{~m}$, were deployed at $\sim 100$-m elevational 
205

206

207

208

209

210

211

212

213

214

215

216

217

218

219

220

221

222

223

224

225

226

227

228

229

230

231

232

233

234

235

236

237

238

239

240

241

242

243

intervals. Audio recorders collected data at each site for approximately one week and were then moved to another elevation transect. Both male and female Eleutherodactylus species are territorial species, and E. coqui does not move more than five meters from their retreat sites (Stewart \& Pough 1983; Woolbright 1985; Gonser \& Woolbright 1995). Calls of all the anuran species from our study site were brodcasted at different distances from the audio recorder, and we estimated the detection range to be $\sim 50 \mathrm{~m}$. Therefore, a site is defined as a three-dimensional hemisphere with a radius of approximately $50 \mathrm{~m}$ around the recorder. Given that the recorders were separated by $>200 \mathrm{~m}$ we assumed that they were independent samples. All recordings were analyzed, permanently stored, and available in the Automated Remote Biodiversity Monitoring Network (ARBIMON) (arbimon.sieve-analytics.com/project/elevation/dashboard).

Audio recorders (LG smartphone enclosed in a waterproof case with an external connector linked to a Monoprice microphone) running the ARBIMON Touch application (https://play.google.com/store) were used to collect the audio recordings. Audio recorders were placed on trees at the height of $1.5 \mathrm{~m}$ and programmed to record 1 minute of audio every $10 \mathrm{~min}$ for a total of $144-1$-minute recordings per day. We manually inspected all recordings from 18:00 to 5:00 (65,187 1-minute recordings ) and marked the presence and absence of each focal species for each day.

\section{Analysis}

\section{Historical distributions - GLM models}

Within the LM, anurans were historically reported from 51 sites, ranging from 39 to 1045 $\mathrm{m}$. The compilation of all historical data provided valuable information about the presence of species, but no data about species absences. Since our goal was to predict species occupancy from the historical data and because predictive methods such as generalized linear models (GLM) require absence data, we generated pseudo-absence data by assigning an absence where there were no reports for species from a site. This procedure allowed us to fit GLM models, which is recommended when absence data are not available (Chefaoui \& Lobo 2008). In this way, all species with a collection record from a site were listed as present, and all other species were listed as absent. This approach provides greater model performance than using randomly sampled pseudo-absence (Lütolf, Kienast \& Guisan 2006). We used this dataset to fit generalized linear models (GLM) using a logistic function in R. Although we are aware that the estimation of occupancy probability using logistic regression may be unrealistic (Ward et al. 2009; Royle et al. 2012) and may underestimate occupancy probability (Kéry, Gardner \& Monnerat 2010; Lahoz-Monfort, Guillera-Arroita \& Wintle 2014), the use of more appropriate analysis, such as the approaches described in Royle and collaborators (2012) and Tingley and Beissinger (2009), were precluded for two reasons: 1) overall sparse data due to a small data set, and 2) lack of repeated visits to the same locality. Nevertheless, our historical quantitative data matches with the available qualitative information about species distribution (Schwartz \& 
244 Henderson 1991; Rivero 1998), and it provides the best summary of the past distributions of 245 these species.

246 We decided not to limit the historical data to those records collected during the same 247 months as the current data (March-May) because there was not enough data from March-May in 248 the historical data to estimate occupancy. In addition, because we could not estimate detection 249 probability from the historical data, the inclusion of a large historical data set improves our 250 251

252

253

254

255

256

257

258

259 ability to determine the presence of the species in the different elevation bands.

Because we were interested in testing for elevational shifts, we included information about elevation as a standardized continous covariate represented by a linear (elevation) and a quadratic (elevation+elevation ${ }^{2}$ ) function. In addition, we included a null model with only the intercept (Null model) in a total of three model parametrizations for each species, simply depicted as:
(1) Occupancy Null
(2) Occupancy $\sim$ Elevation
(3) Occupancy $\sim$ Elevation + Elevation $^{2}$

260

261

262

263

264

265

266

267

268

269

270

271

272

273

274

275

276

277

278

279

280

281

282

283

We used the glmulti package (Calcagno \& de Mazancourt 2010) of R software for model selection based on the lowest AIC value. We compared models using AIC, and we estimated occupancy profiles by model-averaging all models with $\triangle \mathrm{AIC}<2.0$. In addition, we evaluated model fit using the Hosmer-Lemeshow Goodness of fit test, and we found no indication of lack of fit for the best model of each species $(\mathrm{P}>0.05)$.

\section{Current distributions - Occupancy models}

We used a detection/non-detection matrix summarized by day from the acoustic monitoring data set to fit single-species single-season occupancy models using the package Unmarked in $\mathrm{R}$ (Fiske \& Chandler 2011). Because we have a relatively small number of anuran species in LM and because all the focal species were detected several times we chose to use single-species models. We also assume that the population was closed between the two years to reduce model complexity and because change in occupied sites between years were very small for all species (mean 2.45 (+/-2.42) sites changed occupancy status between years). We did not include E. coqui in occupancy analyses because this species was present in all sampling sites along the elevational gradient.

The occupancy state of each sampling site was estimated taking into account imperfect detection, following the standard maximum likelihood hierarchical approach introduced by (Mackenzie et al. 2002). Our models contain a sampling level describing the probability of detection conditioned on occupancy $(p)$, and an underlying biological level describing the probability $(\psi)$ that a site is occupied. Both $p$ and $\psi$ were allowed to vary according to elevation. To estimate elevational profiles of occupancy $(\psi)$ for each species we constructed a set of 
284

285

286

287

288

289

290

291

292

293

294

295

296

297

298

299

300

301

302

303

304

305

306

307

308

309

310

311

312

313

314

315

316

317

318

319

320

321

322

323

competing hypothesis of how occupancy and detection changed over elevation (Kéry, Gardner \& Monnerat 2010). Elevation is a standardized continuous covariate represented by a linear (elevation) and a quadratic (elevation + elevation $^{2}$ ) function. In addition, we included a null model with only the intercept, resulting in a total of nine models per species (Table S4). We have included elevation as a covariate for the detection function because other environmental variables, such as temperature and humidity, are known to change with elevation, and these factors can influence calling behavior, and thus affect the detection probability. An example of the most parametrized occupancy model can be described as:

Biological level - Occupancy $(\psi)$

$\operatorname{logit}(\Psi)=\beta_{0}+\beta_{1}$ elevation $+\beta_{2}$ elevation $^{2}$

$\underline{\text { Sampling level - Detectability }(p)}$

$\operatorname{logit}(p)=\beta_{4}+\beta_{5}$ elevation $+\beta_{6}$ elevation ${ }^{2}$

We compared models using AIC, and we estimated occupancy profiles across the range of elevations sampled by model-averaging all models with $\triangle \mathrm{AIC}<2.0$. All models were fitted using the package Unmarked in $\mathrm{R}$ (Fiske \& Chandler 2011). Summaries for model selection procedures can be found in supplementary material (Table S5, Table S6, Table S7). We used the parametric bootstrap function parboot in Unmarked (1000 interactions) for assessing goodnessof-fit of the best model for each species. We found no indication of lack of fit for our best models $(\mathrm{P}>005)$.

To compare changes in species distributions between historical and current data we conservatively estimated the species distribution range by selecting sites with probability of occupancy equal or higher than 0.1 . By using this conservative approach to determine species range limits we excluded sites with low likelihood to be occupied by the species. Only range shifts greater than 100 meters were considered significant.

\section{Results}

\section{Naïve occupancy data}

A total of 51 unique sampling localities (e.g., sites) were extracted from our historical compilation in the LM over a period of 58 years (1931 to 1989). The most widespread species was E. coqui (53\% sites - 27/51) and E. portoricensis (50\% sites - 25/51), while E. hedrick ( $7.8 \%$ sites $-4 / 51)$, E. unicolor (5.8 \% sites - 3/51) and E. cochranae $(5.8 \%$ sites $-3 / 51)$ were relatively rare (Figure 2 ). The total numbers of species detected varied across the sites with a maximum of eleven species detected at one low elevation site $(371 \mathrm{~m})$.

In contrast, 67 sampling localities were surveyed in 2015 and 2016 and the 12 native frog species known to currently occur in the LM were detected. These species included: 
324 Lepidodactylus abilabris, E. antillensis, E. cochranae, E. brittoni, E. coqui, E. wightmanae, E. 325 hedricki, E. unicolor, E. gryllus, E. locustus, E. richmondi, and E. portoricensis. We did not 326 detect two species (E. eneidae and E. karlschmidti) that are considered extinct (Burrowes et al., 327 2004). The most widespread species was $E$. coqui, detected in all sampling sites ( $100 \%$ sites 328 67/67), and the least common species were E. locustus and E. richmondi ( $\mathrm{n}=6 \%$ sites $-4 / 67$.

329 The total numbers of species detected varied across the sites with a maximum of seven species 330 detected at one high elevation site $(800 \mathrm{~m})$. The naïve occupancy data suggests that six species 331 (E. portoricensis, E. gryllus, E. locustus, E. richmondi, E. eneidae, E. karlschmidti) no longer

332

333 334

335

336

337

338

339

340

341

342

343

344

345

346

347

348

349

350

351

352

353

354

355

356

357

358

359

360

361

362

363 occur below 500 meters (Figure 2). We did not include E. coqui in occupancy analyses because this species was detected along the entire elevational gradient both in the historic and current datasets.

\section{Occupancy modelling}

Elevation plays an important role in amphibian distribution because models with the covariate Elevation performed better $(\triangle \mathrm{AIC}<2)$ than the null model for the majority of species in the historical data set $(n=11 / 14)$ as well in current data $(n=9 / 11)$ (Table 1). Overall, the occupancy probability increases with an increase in elevation in four species (E. portoricensis, $E$. gryllus, E. unicolor, and E. locustus), while there was a negative relationship between occupancy and elevation in four species (E. brittoni, L. albilabris, E. antillensis, and E. cochranae) (Table 1, Figure 3). The occupancy probabilities of E. richmondi and E. hedricki assume a bell-shape distribution with higher occupancy probabilities at intermediary elevation. The historical distribution of $E$. wightmanae indicates a higher occupancy probability at intermediate elevations, while the current distribution shows a slight increase of occupancy with elevation.

The main difference between the past and present distributions of the species can be described by two features: 1) the value of the occupancy probabilities and 2) changes in the distributional range. There was a decrease in occupancy probabilities in five species $(E$. richmondi, E. wightmanae, E. locustus, E. antillensis, and E. cochranae), while there was an increase in occupancy probability for six species (E. portoricensis, E. gryllus, E. unicolor, E. hedricki, E. brittoni, and L. albilabris) (Figure 3). Four species showed a significant range contraction $(>100 \mathrm{~m})$ for the lower end of the elevational distributions (Figure 1S): $E$.

portoricensis (207 to $508 \mathrm{~m}$ ), E. gryllus (39 to $654 \mathrm{~m}$ ), E. locustus (191 to $333 \mathrm{~m}$ ), E. richmondi ( 39 to $654 \mathrm{~m}$ ). There was also signficant range contraction for the upper end of the elevational distribution of two species: E. richmondi (1045 to $800 \mathrm{~m}$ ) and E. antillensis ( 618 to $216 \mathrm{~m}$ ). In addition, we detected a range expansion at the low end of the elevational distribution in $E$. unicolor (908 to $523 \mathrm{~m}$ ) and a range expansion on the upper end of E. hedricki (649 to $1020 \mathrm{~m}$ ). Overall, detection probabilities were high for all species $(0.40>\mathrm{p}<1.00)$ indicating that our acoustic survey provides a robust methodology for detecting anuran species. The covariate Elevation appears in the detection term of the best models ( $\triangle \mathrm{AIC}<2)$ of most species $(82 \%)$ suggesting that this covariate is a good proxy for modeling the influence of other environmental 
364

365

366

367

368

369

370

371

372

373

374

375

376

377

378

379

380

381

382

383

384

385

386

387

388

389

390

391

392

393

394

395

396

397

398

399

400

401

402

403

variables related with elevation, such as humidity and temperature, on detection probability. Moreover, the high detection probabilities estimated provide robust evidence for the lowland extirpation of some species.

\section{Discussion}

In this study, we present quantitative evidence of changes in the distributions of anuran species along an elevational gradient in a protected tropical mountain. Over a span of $\sim 25$ years, two species became extinct and four species suffered extirpation in lowland areas. As a consequence, low elevation areas in the $\operatorname{LM}(<300 \mathrm{~m})$ have lost at least six anuran species. This pattern of local extinction in low elevation sites has been observed for many other species around the world, and climate change is thought to be the major culprit (Burrowes et al. 2004, Wiens 2016). Furthermore, the impacts of global warming are expected to have extensive negative impacts on species richness in lowland tropical areas (Colwell et al. 2008). One possible explanation for population extirpation at the lower end of species distributions is that species may be exceeding their maximum thermal tolerance (Deutsch et al. 2008) due to warming temperatures. Moreover, the loss of species in tropical lowlands is especially troublesome given that there are rarely species from hotter areas to colonize the lowlands (Colwell et al. 2008).

Although our results indicate changes in the elevational distributions of some species, there were two limitations with the historical data: 1) lack of information on non-detection and 2) absences of replicate visits in a short time frame. Consequently, our historical data set may have false absences, biasing our comparisons. In addition, we were not able to estimate detection probabilities, which can lead to bias and an underestimation of occupancy probabilities (Kéry, Gardner \& Monnerat 2010). Misidentification error and taxonomic changes could also be a relevant source of bias. Moreover, all historical data inherently suffer from geographical imprecision and survey-specific characteristics such as effort, different methodologies, and variability in observer skills (Tingley \& Beissinger 2009). Despite these intrinsical limitations, our historical quantitative data set reflects the available qualitative description of species distribution range, and it offers our best knowledge about the historical distribution of the species. We also recognize that it may be a challenge to confidently concluded on extirpations, given the limited temporal coverage of the acoustic sampling, but we also emphasize that our survey, which covered 67 sampling sites along three elevational transects in two different years is the most extensive every conducted in one of the most studied tropical forest in the world.

Although these limitations limits inferences on colonization, we can provide inferences for local extinction (Tingley and Beissinger 2009). For instance, there are many records, including museum specimens, indicating that $E$. gryllus historically occurred in lower elevation sites (e.g. $300 \mathrm{~m}$ ) and now it can only be found above $600 \mathrm{~m}$. Any bias and underestimation of occupancy probabilities would be more likely to affect our comparisons when the occupancy probabilities from the historical data sets are lower than the current occupancy probabilities. Therefore, the historical biases in the data results in conservative estimates of range contractions. 
404

405

406

407

408

409

410

411

412

413

414

415

416

417

418

419

420

421

422

423

424

425

426

427

428

429

430

431

432

433

434

435

436

437

438

439

440

441

442

443

The observed pattern of species extirpation at low elevations areas is supported by long-term monitoring projects centered around the El Verde Field Station (350 - 450 m) (Stewart 1995) (Woolbright 1997). The El Verde Field Station is the most studied site in LM and there is strong evidence that of the seven species that were relatively common before 1990, only E. coqui and E. hedricki are still common, while E. gryllus, E. portoricensis, E. richmondi, E. eneidae, and E. wightmanae are now locally extinct (Drewry \& Rand 1983; Woolbright 1997; Stewart 1995) (GBIF, 2016). Woolbright (1997) extended his study beyond the El Verde Field Station and noted an overall pattern of local extinctions at lower elevation sites within the Tabonuco forest. Furthermore, E. richmondi, E. wightmanae, and E. locustus were also described to have become locally extinct at middle $(661 \mathrm{~m})$ and at high elevation sites $(850 \mathrm{~m})$ in EYNF around 1990 (Joglar \& Burrowes 1996). Our study confirms the results of these two long-term studies given that E. locustus, E. richmondi, E. gryllus, E. portoricensis and E. wightmanae are now relatively rare in the LM and, with the exception of E. wightmanae, these species no longer occur in low elevations $(<500 \mathrm{~m})$. Anecdotal descriptions of elevational shifts indicate an upward shift for $E$. gryllus, E. portoricensis, and E. richmondi and a downward shift for E. hedricki (Joglar 1998). Our results also agree with a general upward shift for E. gryllus, E. portoricensis, and E. richmondi, but there is no evidence for a downward shift for E. hedricki.

The declines and extirpations of the anurans populations in Puerto Rico between 1970 and 1990 (Moreno 1991; Stewart 1995; Woolbright, 1996; Woolbright, 1997; Burrowes, Joglar \& Green 2004), has intrigued the scientific community since many of these declines have happened in protected areas. We hypothesized that the distributions shifts documented in this study are the consequence of climate change, including increases in periods of droughts, and chytrid fungus, as previously proposed by other researchers (Joglar \& Burrowes 1996; Burrowes, Joglar \& Green 2004; Lips et al. 2005). Evidences for this hypothesis can be summarized as follow: First, there has been no obvious direct anthropogenic impact in the LM during the period of decline, and the LM remains one of the best-preserved forests in Puerto Rico. Second, the average temperature in Puerto Rico has increased by approximately $2.24{ }^{\circ} \mathrm{C}$ from 1950 to 2014, with an increase in minimum temperature of $0.048^{\circ} \mathrm{C} /$ year and an increase in maximum temperature $0.022^{\circ} \mathrm{C} /$ year (Méndez-Tejeda, 2017). Studies have shown a significant increase in annual mean temperature $\left(0.007^{\circ} \mathrm{C} \mathrm{yr}^{-1}\right)$ over 62 years (1932-1994) in the lowlands (100-450m) of LM (Greenland \& Kittel 2002), and a significant increase in the mean minimum temperature and a decrease in mean precipitation from 1970 to 2000 in the East Peak (1051 m) (Lasso \& Ackerman 2003). In addition, analyses of climate data from local weather stations showed an increase in the frequency of dry periods and prolonged dry seasons between 1970 and 1990, coincident with amphibian declines (Stewart 1995; Burrowes, Joglar \& Green 2004). Models also suggest that warming temperatures will continue with drier wet seasons, and drier dry seasons in the LM and the Caribbean (Scatena 1998; Campbell et al. 2011). Although Eleutherodactylus frogs do not depend on water bodies for reproduction, these species need cool temperatures and humid sites to prevent dehydration and desiccation of eggs, and prolonged periods of drought significantly decreased E. coqui population densities in the EYNF (Stewart 1995). Prolonged drought can 
444 also reduce foraging success of coquis (Woolbright \& Stewart 1987). In addition, there is a

445

446

447

448

449

450

451

452

453

454

455

456

457

458

459

460

461

462

463

464

465

466

467

468

469

470

471

472

473

474

475

476

477

478

479

480

481

482

483

negative impact of drought on the behavior and activity patterns of E. coqui (Pough et al. 1983;

Stewart 1995), as well as on the infection levels of the pathogenic chytrid fungus (Longo, Burrowes \& Joglar 2010).

The Batrachochytrium dendrobatidis fungus $(\mathrm{Bd})$ is another potential cause of widespread amphibian decline. Bd has been identified in more than 700 species of amphibians, and it has been associated with species extinctions, mass mortality events, and population declines (Stuart et al. 2004; Lips et al. 2005; Lips et al. 2006; Skerratt et al. 2007; Lips 2016). Although no dieoffs have been observed in Puerto Rico, there is evidence linking $\mathrm{Bd}$ and amphibian declines (Burrowes, Joglar \& Green 2004; Longo et al. 2013). Bd was found in the preserved skins of $E$. coqui collected in 1978, and E. karlschmidti collected in 1976, coinciding with the beginning of declines of these species in the LM (Burrowes, Joglar \& Green 2004), and it has been detected in nine Eleutherodactylus species as well as in Leptodactylus albilabris (Burrowes, Longo \& Joglar 2008). There is also evidence supporting the interacting effects of climate change and $\mathrm{Bd}$ as main cause of amphibian declines (Pounds et al. 2006; Grant et al. 2016). In Puerto Rico, the synergetic effect of climate change and disease have been proposed to explain local declines (Burrowes, Joglar \& Green 2004). Climate change may act directly on the pathogen, trigging outbreaks by changing the pathogens developmental and survival rates (Harvell et al. 2002). For instance, warming temperatures may favor Bd optimum growth inducing outbreaks (Pounds et al. 2006). In contrast, climate change may act on the host changing its behavior, phenology, and physiology (Burrowes 2009), and consequently increasing its susceptibility to the pathogen. For instance, coquis stressed by dehydration aggregate in humid refuges during dry periods, which likely increases the probability of disease transmission (Longo, Burrowes \& Joglar 2006). While Bd may pose a serious threat to frogs in EYNF, studies are needed to assess its impact on species distributions along the entire elevational gradient.

Our study provides a quantitative description of elevational shifts in anuran species in a tropical mountain, and a quantitative baseline for future studies of these species. From a conservation perspective, we identified species that may be more vulnerable to extinction due to range contractions and because these species are being pushed to higher elevations where there is much less land area. For example, our acoustic data showed that four species no longer occur below $500 \mathrm{~m}$ (E. locustus, E. richimondi, E. portoricensis. E. gryllus). Furthermore, E. richimondi was only found in a narrow elevational range $(<350 \mathrm{~m})$, and both $E$. richimondi and E. locustus are now relatively rare. Possibly, the most vulnerable species is E. gryllus that reach its highest occupancy probabilities above $900 \mathrm{~m}$, only $174 \mathrm{~m}$ from the top of the mountain. The extremely narrow elevational ranges exhibited by these species are especially worrisome because there are only limited connections to other high elevation forest sites in Puerto Rico, and this would require extensive movement through lowland forests, agricultural lands, and urban areas.

These shifts in distribution along the elevation gradient are creating new ecological communities, which could impact ecosystem function given that anurans are the largest component of nocturnal biomass of all vertebrates in Puerto Rico (Stewart 1995) and are 
484 fundamental components of the food web (Beard et al. 2003; Whiles et al. 2006). While

485

486

487

488

489

490

491

492

493

494

495

496

497

498

499

500

501

502

503

504

505

506

507

508

509

510

511

512

513

514

515

516

517

518

519

520

521

522

523

524

historically the distributions of 11 coqui species overlapped in the lowlands $(371 \mathrm{~m})$, today the elevation with the greatest richness (seven species) occurs at $800 \mathrm{~m}$. Of greatest concern, is the loss of six coqui species below $500 \mathrm{~m}$. This biotic attrition in the lowlands is likely to change interspecific interactions affecting the function of these biological communities (Colwell et al. 2008).

\section{Conclusions}

In this study, we have shown how acoustic surveys can be used to monitor species, provide data to confirm general impressions of amphibian population extirpations at certain sites/elevations, and corroborate the level of threat of species as considered by IUCN. Two critically endangered species (E. eneidae and E. karlschmidti) have not been detected since 1974 and 1990, despite our efforts and those of previous researchers. Two species considered critically endangered (E. locutus and E. richmondi) and two endangered species (E. portoricensis and E. gryllus) suffered range contractions $>100 \mathrm{~m}$ caused by extirpation in the lowlands. Here, we provide recommendations to improve the conservation of these threatened species: 1) The establishment of a long-term monitoring project to monitor species distributions. Widespread, frequent, and long-term monitoring is necessary to understand the causes and consequences of amphibian decline, and to focus conservation and management activities (Lips et al. 2005); 2) captive breeding of the four species that suffered lowland extirpation. Captive breeding is often the easiest and most cost-effective method to manipulate and conserve the population of many species (Brooks, Wright \& Sheil 2009; Zippel et al. 2011).

\section{Acknowledgements}

We thank Paul Furumo, Serge Aucoin, Felipe Caño and Pedro Rio (USDA Forest Service), Orlando Acevedo, and Andres Hernandez for assistance with data collection. We thank Joseph M. Wunderle, Patricia A. Burrowes and Miguel A. Acevedo for their comments on the manuscript, and Charles Yackulic for help with the occupancy analyses.

\section{References}

Beard, K.H., Eschtruth, A.K., Vogt, K. A., Vogt, D.J. \& Scatena, F.N. (2003) The effects of the frog Eleutherodactylus coqui on invertebrates and ecosystem processes at two scales in the Luquillo Experimental Forest, Puerto Rico. Journal of Tropical Ecology, 19, 607-617.

Briscoe, C.B. (1966) Weather in the Luquillo Mountains of Puerto Rico. San Juan.

Brokaw, N., Crowl, T., Lugo, A., McDowell, W., Scatena, F., Waide, R. \& Willig, M. (2012) A Caribbean Forest Tapestry: The Multidimensional Nature of Disturbance and Response (ed N Brokaw). Oxford University Press.

Brooks, T., Wright, S.J. \& Sheil, D. (2009) Evaluating the Success of Conservation Actions in Safeguarding Tropical Forest Biodiversity. Conservation Biology, 23, 1448-1457. 
525

526

527

528

529

530

531

532

533

534

535

536

537

538

539

540

541

542

543

544

545

546

547

548

549

550

551

552

553

554

555

556

557

558

559

560

561

562

563

564

565

566

567

568

569

570

Burrowes, P. (2009) Climate Change and Amphibian Declines. Amphibian Biology Vol 8: Amphibian Decline: Diseases, Parasites, Maladies and Pollution (eds H. Heatwole), \& J.W. Wilkinson), pp. 3268-3287. Surrey Beatty and Sons Publishers, Australia.

Burrowes, P.A., Joglar, R. \& Green, D. (2004) Potential causes for amphibian declines in Puerto Rico. Herpetologica, 60, 141-154.

Burrowes, P.A., Longo, A. V. \& Joglar, R.L. (2008) Geographic distribution of Batrachochytrium dendrobatidis in Puerto Rico. Herpetological Review, 39, 321-324.

Bustamante, M.R., Ron, S.R. \& Coloma, L.A. (2005) Cambios en la diversidad en siete comunidades de anuros en los Andes de Ecuador. Biotropica, 37, 180-189

Calcagno, V. \& de Mazancourt, C. (2010) glmulti: an R package for easy automated model selection with (generalized) linear models. Journal of Statistical Software, 34, 1-29.

Campbell, J.D., Taylor, M.A., Stephenson, T.S., Watson, R.A. \& Whyte, F.S. (2011) Future climate of the Caribbean from a regional climate model. International Journal of Climatology, 31, 1866-1878

Campos-Cerqueira, M. \& Aide, T.M. (2016) Improving distribution data of threatened species by combining acoustic monitoring and occupancy modelling. Methods in Ecology and Evolution, 7, 1340-1348.

Campos-Cerqueira, M; Arendt, W.J; Wunderle, J.M; Aide, T.M. (2017) Have bird distributions shifted along an elevational gradient on a tropical mountain? " Ecology and Evolution in press

Chefaoui, R.M. \& Lobo, J.M. (2008) Assessing the effects of pseudo-absences on predictive distribution model performance. Ecological Modelling, 210, 478-486.

Chen, I., Hill, J.K., Ohlemüller, R., Roy, D.B. \& Thomas, C.D. (2011) Rapid range shifts of species associated with high levels of climate warming. Science, 333, 1024-1026.

Collins, J.P., Crump, M.L. \& Lovejoy III, T.E. (2009) Extinction in Our Times: Global Amphibian Decline. Oxford University Press.

Colwell, R.K., Brehm, G., Cardelús, C.L., Gilman, A.C. \& Longino, J.T. (2008) Global warming, elevational range shifts, and lowland biotic attrition in the wet tropics. Science, 322, 258-261.

Crump, M.L., Hensley, F.R. \& Clark, K.L. (1992) Apparent decline of the golden toad: underground or extinct? Copeia, 2, 413-420.

Deutsch, C.A., Tewksbury, J.J., Huey, R.B., Sheldon, K.S., Ghalambor, C.K., Haak, D.C. \& Martin, P.R. (2008) Impacts of climate warming on terrestrial ectotherms across latitude. Proceedings of the National Academy of Sciences of the United States of America, 105, 6668-6672.

Drewry, G.E. \& Rand, A.S. (1983) Characteristics of an acoustic community: Puerto Rican frogs of the genus Eleutherodactylus. Copeia, 941-953.

Feeley, K.J. \& Silman, M.R. (2011) The data void in modeling current and future distributions of tropical species. Global Change Biology, 17, 626-630.

Feeley, K.J., Silman, M.R., Bush, M.B., Farfan, W., Cabrera, K.G., Malhi, Y., Meir, P., Revilla, N.S., Quisiyupanqui, M.N.R. \& Saatchi, S. (2011) Upslope migration of Andean trees. Journal of Biogeography, 38, 783-791.

Ficetola, G.F. \& Maiorano, L. (2016) Contrasting effects of temperature and precipitation change on amphibian phenology, abundance and performance. Oecologia, 181, 683-693.

Fiske, I.J. \& Chandler, R.B. (2011) Unmarked: An R Package for Fitting Hierarchical Models of Wildlife Occurrence and Abundance. Journal of Statistical Software, 43, 1-23. 
571 Forero-Medina, G., Terborgh, J., Socolar, S.J. \& Pimm, S.L. (2011) Elevational ranges of birds

572

573

574

575

576

577

578

579

580

581

582

583

584

585

586

587

588

589

590

591

592

593

594

595

596

597

598

599

600

601

602

603

604

605

606

607

608

609

610

611

612

613

614

615

616

on a tropical montane gradient lag behind warming temperatures. PloS one, 6, e28535.

GBIF. (2016) Global Biodiversity Information Facility. < http://www.gbif.org/> (accessed 03.2016).

Gonser, R.A. \& Woolbright, L.L. (1995) Homing Behavior of the Puerto Rican Frog, Eleutherodactylus coqui. Journal of Herpetology, 29, 481-484.

González, G., García, E., Cruz, V., Borges, S., Zalamea, M. \& Rivera, M.M. (2007) Earthworm communities along an elevation gradient in Northeastern Puerto Rico. European Journal of Soil Biology, 43, S24-S32.

Gould, W.A., Alarcon, C., Fevold, B., Jimenez, M.E., Martinuzzi, S., Potts, G., Quiñones, M., Solórzano, M., Ventosa, E. \& others. (2008) The Puerto Rico Gap Analysis Project Volume 1: Land Cover, Vertebrate Species Distributions, and Land Stewardship. Puerto Rico.

Gould, W.A., Gonzalez, G. \& Rivera, C. (2006) Structure and composition of vegetation along an elevational gradient in Puerto Rico. Journal of Vegetation Science, 17, 653-664.

Gradstein, S.R., Homeier, J. \& Gansert, D. (2008) The Tropical Mountain Forest Patterns and Processes in a Biodiversity Hotspot (eds SR Gradstein, J Homeier, and D Gansert). Universitätsverlag Göttingen, Göttingen, Germany.

Grant, E.H.C., Miller, D.A.W., Schmidt, B.R., Adams, M.J., Amburgey, S.M., Chambert, T., Cruickshank, S.S., Fisher, R.N., Green, D.M., Hossack, B.R., Johnson, P.T.J., Joseph, M.B., Rittenhouse, T.A.G., Ryan, M.E., Hardin Waddle, J., Walls, S.C., Bailey, L.L., Fellers, G.M., Gorman, T.A. \& Ray, A.M. (2016) Quantitative evidence for the effects of multiple drivers on continental-scale amphibian declines. Nature Publishing Group, 6, 256225.

Greenland, D. \& Kittel, T.G.F. (2002) Temporal variability of climate at the US Long-Term Ecological Research (LTER) sites. Climate Research, 19, 213-231.

Harris, J.B.C.H., Yong, D.L., Sheldon, F.H., Boyce, A.J., Eaton, J.A., Bernard, H., Biun, A., Langevin, A., Martin, T.E. \& Wei, D. (2012) Using diverse data sources to detect elevational range changes of birds on Mount Kinabalu, Malaysian Borneo. Raffles Bulletin of Zoology, 197-247.

Harvell, C.D., Mitchell, C.E., Ward, J.R., Altizer, S., Dobson, A.P., Ostfeld, R.S. \& Samuel, M.D., 2002. Climate warming and disease risks for terrestrial and marine biota. Science, 296, 2158-2162

Hedges, S.B. (1993) Global amphibian declines: a perspective from the Caribbean. Biodiversity and Conservation, 2, 290-303.

Heyer, W. Ronald, A. Stanley Rand, Carlos Alberto Goncalvez da Cruz, \& Oswaldo L. Peixoto. (1988) Decimations, extinctions, and colonizations of frog populations in southeast Brazil and their evolutionary implications. Biotropica, 20, 230-235.

Hirschfeld, M; Blackburn, D.C; Doherty-Bone, T.M; Gonwouo, L.N; Ghose, S; Rödel, M-O. (2016) Dramatic Declines of Montane Frogs in a Central African Biodiversity Hotspot. PLoS ONE, 11, e0155129.

Joglar, R. (1998) Los Coquíes de Puerto Rico: Su Historia Natural Y Conservación, Primera ed. Universidad de Puerto Rico, San Juan.

Joglar, R.L. \& Burrowes, P. (1996) Declining amphibian populations in Puerto Rico. Contributions to West Indian Herpetology: A tribute to Albert Schwartz (eds R. Powell), \& R. Henderson), pp. 371-380. Ithaca.

Kéry, M., Gardner, B. \& Monnerat, C. (2010) Predicting species distributions from checklist data using site-occupancy models. Journal of Biogeography, 37, 1851-1862.

PeerJ reviewing PDF | (2017:08:19637:2:0:NEW 23 Oct 2017) 
617 Lahoz-Monfort, J.J., Guillera-Arroita, G. \& Wintle, B.A. (2014) Imperfect detection impacts the 618 performance of species distribution models. Global Ecology and Biogeography, 23, 504619515.

620

621

622

623

624

625

626

627

628

629

630

631

632

633

634

635

636

637

638

639

640

641

642

643

644

645

646

647

648

649

650

651

652

653

654

655

656

657

658

659

660

661

662

La Marca, E. \& Reinthaler, H.P. (1991) Population changes in Atelopus species of the Cordillera de Mérida, Venezuela. Herpetological Review, 22, 125-128.

Lasso, E. \& Ackerman, J.D. (2003) Flowering phenology of Werauhia sintenisii, a bromeliad from the dwarf montane forest in Puerto Rico: an Indicator of climate change? Selbyana, 24, 95-104.

Laurance, W.F., McDonald, K.R. \& Speare, R. (1996) Epidemic disease and the catastrophic decline of Australian rain forest frogs. Conservation Biology, 10, 406-413.

Lenoir, J., Gégout, J.C., Marquet, P.A., de Ruffray, P. \& Brisse, H. (2008) A significant upward shift in plant species optimum elevation during the 20th century. Science, 320, 1768-1771.

Lenoir, J. \& Svenning, J.-C. (2014) Climate-related range shifts - a global multidimensional synthesis and new research directions. Ecography, 38, 15-28.

Lips, K. R. (1999) Mass mortality and population declines of anurans at an upland site in western Panama. Conservation Biology 13, 117- 125.

Lips, K.R., Burrowes, P.A., Mendelson, J.R. \& Parra-Olea, G. (2005) Amphibian population declines in Latin America: A synthesis. Biotropica, 37, 222-226.

Lips, K.R., Brem, F., Brenes, R., Reeve, J.D., Alford, R.A., Voyles, J., Carey, C., Livo, L., Pessier, A.P. \& Collins, J.P. (2006) Emerging infectious disease and the loss of biodiversity in a Neotropical amphibian community. Proceedings of the National Academy of Sciences of the United States of America, 103, 3165-3170.

Lips, K. (2016) Overview of Chytrid Emergence and Impacts on Amphibians. Philosophical Transactions of the Royal Society, B 371, 20150465.

Longo, A. V., Burrowes, P.A. \& Joglar, R.L. (2006) Study of the effect of drought on the dispersion pattern of rainforest Eleutherodactylus. 20th AAAS conference

Longo, A. V., Burrowes, P.A. \& Joglar, R.L. (2010) Seasonality of Batrachochytrium dendrobatidis infection in direct-developing frogs suggests a mechanism for persistence. Diseases of Aquatic Organisms, 92, 253-260.

Longo, A. V, Ossiboff, R.J., Zamudio, K.R. \& Burrowes, P.A. (2013) Lability in Host Defenses: Terrestrial Frogs Die from Chytridiomycosis under Enzootic Conditions. Journal of Wildlife Diseases, 49, 197-199.

Lugo, A.E. (1994) Preservation of primary forests in the Luquillo Mountains, Puerto Rico. Conservation biology, 8, 1122-1131.

Lütolf, M., Kienast, F. \& Guisan, A. (2006) The ghost of past species occurrence: Improving species distribution models for presence-only data. Journal of Applied Ecology, 43, 802815.

Mackenzie, D.I., Nichols, J.D., Lachman, G.B., Droege, S., Andrew Royle, J., Langtimm, C.A., Andrew, J. \& Langtimm, C.A. (2002) Estimating site occupancy rates when detection probabilities are less than one. Ecology, 83, 2248-2255.

Moreno, J.A. (1991) Status y distribución de los reptiles y anfibios de la región de Puerto Rico. Departamento de Recursos Naturales de Puerto Rico, 1-35.

Parmesan, C. (2006) Ecological and evolutionary responses to recent climate change. Annual Review of Ecology, Evolution, and Systematics, 37, 637-669.

Pough, F.H., Taigen, T.L., Stewart, M.M. \& Brussard, P.F. (1983) Behavioral modification of evaporative water loss by a Puerto Rican frog. Ecology, 64, 244-252. 
663 Pounds, J. \& Crump, M. (1994) Amphibian declines and climate disturbance: the case of the

664

665

666

667

668

669

670

671

672

673

674

675

676

677

678

679

680

681

682

683

684

685

686

687

688

689

690

691

692

693

694

695

696

697

698

699

700

701

702

703

704

705

706

707

708 golden toad and the harlequin frog. Conservation Biology, 8, 72-85.

Pounds, J.A., Fogden, M.P.L. \& Campbell, J.H. (1999) Biological response to climate change on a tropical mountain. Nature, 398, 611-615.

Pounds, J.A., Bustamante, M.R., Coloma, L.A., Consuegra, J.A., Fogden, M.P.L., Foster, P.N., La Marca, E., Masters, K.L., Merino-Viteri, A., Puschendorf, R., Ron, S.R., SánchezAzofeifa, G.A., Still, C.J. \& Young, B.E. (2006) Widespread amphibian extinctions from epidemic disease driven by global warming. Nature, 439, 161-7.Raxworthy, C.J., Pearson, R.G., Rabibisoa, N., Rakotondrazafy, A.M., Ramanamanjato, J.-B.B., Raselimanana, A.P., Wu, S., Nussbaum, R.A. \& Stone, D. a. (2008) Extinction vulnerability of tropical montane endemism from warming and upslope displacement: a preliminary appraisal for the highest massif in Madagascar. Global Change Biology, 14, 1703-1720.

Richards, S.J., McDonald, K.R. \& Alford, R.A. (1994) Declines in populations of Australia's endemic tropical rainforest frogs. Pacific Conservation Biology, 1, 66-77.

Rivero, J.A. (1998) Los Anfibios Y Reptiles de Puerto Rico. University of Puerto Rico Press, San Juan, Puerto Rico.

Di Rosa, I., Simoncelli, F., Fagotti, A. \& Pascolini, R. (2007) Ecology - the proximate cause of frog declines? Nature, 447, E4-E5.

Royle, J.A., Chandler, R.B., Yackulic, C. \& Nichols, J.D. (2012) Likelihood analysis of species occurrence probability from presence-only data for modelling species distributions. Methods in Ecology and Evolution, 3, 545-554.

Scatena, F.N. (1998) An assessment of climate change in the Luquillo Mountains of Puerto Rico. Third International Symposium on Water Resources, San Juan, Puerto Rico. American Water Resources Association, Washington, DC pp. 193-198.

Schwartz, A. \& Henderson, R.W. (1991) Amphibians and Reptiles of the West Indies: Descriptions, Distributions and Natural History. University Press of Florida, Florida.

Seimon, T.A., Seimon, A., Daszak, P., Halloy, S.R.P., Schloegel, L.M., Aguilar, C.A., Sowell, P., Hyatt, A.D., Konecky, B. \& Simmons, J.E. (2007) Upward range extension of Andean anurans and chytridiomycosis to extreme elevations in response to tropical deglaciation. Global Change Biology, 13, 288-299.

Sekercioglu, C.H., Schneider, S.H., Fay, J.P. \& Loarie, S.R. (2008) Climate change, elevational range shifts, and bird extinctions. Conservation biology, 22, 140-150.

Skerratt, L.F., Berger, L., Speare, R., Cashins, S., McDonald, K.R., Phillott, A.D., Hines, H.B. \& Kenyon, N. (2007) Spread of chytridiomycosis has caused the rapid global decline and extinction of frogs. EcoHealth, 4, 125-134.

Stewart, M. (1995) Climate driven population fluctuations in rain forest frogs. Journal of Herpetology, 29, 437-446.

Stewart, M.M. \& Pough, F.H. (1983) Population density of tropical forest frogs: relation to retreat sites. Science, 221, 570-572.

Still, C.J., Foster, P.N. \& Schneider, S.H. (1999) Simulating the effects of climate change on tropical montane cloud forests. Nature, 398, 608-610.

Stuart, S.N., Chanson, J.S., Cox, N. a, Young, B.E., Rodrigues, A.S.L., Fischman, D.L. \& Waller, R.W. (2004) Status and trends of amphibian declines and extinctions worldwide. Science, 306, 1783-1786.

Tingley, M.W. \& Beissinger, S.R. (2009) Detecting range shifts from historical species occurrences: new perspectives on old data. Trends in ecology \& evolution, 24, 625-633. 
709

710

711

712

713

714

715

716

717

718

719

720

721

722

723

724

725

726

727

728

729

730

731

732

733

734

735

736

737

738

739

740

741

742

743

744

745

746

747

748

749

750

751

752

753

754

Villanueva-Rivera, L. (2014) Eleutherodactylus frogs show frequency but no temporal partitioning: implications for the acoustic niche hypothesis. PeerJ 2:e496.

Waide, R.B., Comarazamy, D.E., González, J.E., Hall, C.A.S., Lugo, A.E., Luvall, J.C., Murphy, D.J., Ortiz-zayas, J.R., Ramírez-beltran, N.D., Scatena, N. \& Silver, W.L. (2013) Climate variability at multiple spatial and temporal scales in the Luquillo Mountains, Puerto Rico. Ecological Bulletins, 54, 21-41.

Wang, H.Q., Cornell, J.D., Hall, C.A.S. \& Marley, D.P. (2002) Spatial and seasonal dynamics of surface soil carbon in the Luquillo Experimental Forest, Puerto Rico. Ecological Modelling, 147, 105-122.

Wang, H., Hall, C. a. S., Scatena, F.N., Fetcher, N. \& Wu, W. (2003) Modeling the spatial and temporal variability in climate and primary productivity across the Luquillo Mountains, Puerto Rico. Forest Ecology and Management, 179, 69-94.

Ward, G., Hastie, T., Barry, S., Elith, J. \& Leathwick, J.R. (2009) Presence-only data and the EM algorithm. Biometrics, 65, 554-563.

Weaver, P.L. (2000) Environmental gradients affect forest structure in Puerto Rico's Luquillo Mountains. Interciencia, 25, 254-259.

Weaver, P. \& Gould, W. (2013) Forest vegetation along environmental gradients in northeastern Puerto Rico. Ecological Bulletins, 54, 43-65.

Weaver, P.L. \& Murphy, P.G. (1990) Forest structure and productivity in Puerto Rico's Luquillo Mountains. Biotropica, 22, 69-82.

Whiles, M.R., Lips, K.R., Pringle, C.M., Kilham, S.S., Bixby, R.J., Brenes, R., Connelly, S., Colon-Gaud, J.C., Hunte-Brown, M., Huryn, A.D., Montgomery, C. \& Peterson, S. (2006) The effects of amphibian population declines on the structure and function of Neotropical stream ecosystems. Frontiers in Ecology and the Environment, 4, 27-34.

Whitfield, S.M., Lips, K.R. \& Donnelly. (2016) Amphibian decline and conservation in Central America. Copeia, 1-30.

Wiens, J.J. (2016) Climate-related local extinctions are already widespread among plant and animal species. PLoS Biology, 1-18.

Williams, J.W., Jackson, S.T. \& Kutzbach, J.E. (2007) Projected distributions of novel and disappearing climates by 2100 AD. PNAS, 104, 5738-5742.

Willig, M.R., Presley, S.J., Bloch, C.P., Castro-Arellano, I., Cisneros, L.M., Higgins, C.L. \& Klingbeil, B.T. (2011) Tropical metacommunities along elevational gradients: effects of forest type and other environmental factors. Oikos, 120, 1497-1508.

Winter, M., Fiedler, W., Hochachka, W.M., Koehncke, A., Meiri, S. \& De la Riva, I., 2016. Patterns and biases in climate change research on amphibians and reptiles: a systematic review. Royal Society open science, 3,160158.

Woolbright, L.L. (1985) Patterns of nocturnal movement and calling by the tropical frog Eleutherodactylus coqui. Herpetologica, 41, 1-9.

Woolbright, L. (1996) Disturbance influences long-term population patterns in the Puerto Rican frog, Eleutherodactylus coqui (Anura: Leptodactylidae). Biotropica, 28, 493-501.

Woolbright, L.L. (1997) Local extinctions of anuran amphibians in the Luquillo Experimental Forest of Northeastern Puerto Rico. Journal of Herpetology, 31, 572-576.

Woolbright, L.L. \& Stewart, M.M. (1987) Foraging success of the tropical frog, Eleutherodactylus coqui: The Cost of Calling. Copeia, 1987, 69-75.

WWF. (2016) Living Planet Report 2016. Risk and Resilience in a New Era. Gland, Switzerland, Switzerland. 
755 Zippel, K., Johnson, K., Gagliardo, R., Gibson, R., Mcfadden, M., Browne, R.K., Martinez, C. \& 756 Townsend, E. (2011) The Amphibian Ark: a global community for ex situ conservation of 757 amphibians. Herpetological Conservation and Biology, 6, 340-352.

758

759 


\section{Table $\mathbf{1}$ (on next page)}

Comparison of elevation distribution of 14 frog species in the Luquillo Mountains, Puerto Rico.

Given are IUCN status (EN = endangered; $C R=$ Critically endangered; VU = Vulnerable; $L C=$ Low concern, $t=$ Extinct, $*=$ Endemic), the best supported occupancy model (Elev $=$ elevation; NA = not analyzed) and the cumulative Akaike's Information Criterion weight for all models with those terms (Weight). 
1 Table 1. Comparison of elevation distribution of 14 frog species in the Luquillo Mountains, 2 Puerto Rico. Given are IUCN status (EN = endangered; $\mathrm{CR}=$ Critically endangered; $\mathrm{VU}=$

3 Vulnerable; LC $=$ Low concern, $\uparrow=$ Extinct, $*=$ Endemic), the best supported occupancy model $4 \quad($ Elev = elevation; NA = not analyzed $)$ and the cumulative Akaike's Information Criterion weight 5 for all models with those terms (Weight).

6

\begin{tabular}{|c|c|c|c|c|c|c|c|c|c|}
\hline \multirow[b]{2}{*}{ Species } & \multirow[b]{2}{*}{$\begin{array}{l}\text { IUCN } \\
\text { status }\end{array}$} & \multicolumn{4}{|c|}{ Distributions (m) } & \multicolumn{4}{|c|}{ Occupancy modeling } \\
\hline & & Historic & Current & $\begin{array}{r}\text { Shift Lower } \\
\text { range }\end{array}$ & $\begin{array}{r}\text { Shift Upper } \\
\text { range }\end{array}$ & $\begin{array}{r}\text { Best } \\
\text { model }(\mathrm{H})\end{array}$ & $\begin{array}{r}\text { Best } \\
\text { model (C) }\end{array}$ & $\begin{array}{r}\text { Weight } \\
\text { (H) }\end{array}$ & $\begin{array}{r}\text { Weight } \\
\text { (C) }\end{array}$ \\
\hline E. portoricensis* & EN & $207-1045$ & $508-1049$ & -301 & +4 & Elev $^{2}$ & Elev $^{2}$ & 0.70 & 0.50 \\
\hline E. gryllus* & $\mathrm{EN}$ & $39-1045$ & $654-1049$ & -615 & +4 & Null & Elev & 0.38 & 0.65 \\
\hline E. locustus* & $\mathrm{CR}$ & $191-1045$ & $333-1049$ & -142 & +4 & Elev & Null & 0.67 & 0.55 \\
\hline E. richmondi* & $\mathrm{CR}$ & $39-1045$ & $654-800$ & -615 & -245 & Elve $^{2}$ & Elev $^{2}$ & 0.54 & 0.85 \\
\hline E. wightmanae* & EN & $39-1015$ & $84-1049$ & +45 & +34 & Elev $^{2}$ & Null & 0.93 & 0.60 \\
\hline E. hedricki* & EN & $329-649$ & $362-1020$ & +33 & +371 & Elev $^{2}$ & Elev $^{2}$ & 0.59 & 1.00 \\
\hline E. unicolor* & VU & $908-1045$ & $523-1049$ & 385 & +4 & Elev & Elev & 0.71 & 0.54 \\
\hline E. brittoni ${ }^{*}$ & $\mathrm{LC}$ & $39-740$ & $84-800$ & +45 & +60 & Elev & Elev $^{2}$ & 0.52 & 0.87 \\
\hline L. albilabris & LC & $39-1045$ & $84-1049$ & +45 & +4 & Null & Elev & 0.64 & 0.49 \\
\hline E. coqui & LC & $39-1045$ & 84-1049 & +45 & +4 & Null & NA & 0.64 & NA \\
\hline E. antillensis & LC & $39-618$ & $84-216$ & +45 & -402 & Elev & Elev & 0.70 & 0.70 \\
\hline E. cochranae & LC & $39-222$ & $84-245$ & +45 & +23 & Elev & Elev & 0.48 & 0.55 \\
\hline E. eneidae* & $\mathrm{CR} \dagger$ & $268-1045$ & NA & NA & NA & Elev $^{2}$ & NA & 0.51 & NA \\
\hline E. karlschmidti* & $\mathrm{CR} \dagger$ & $130-786$ & NA & NA & NA & Elev $^{2}$ & NA & 0.50 & NA \\
\hline
\end{tabular}

7 


\section{Figure 1}

Map of the Luquillo Mountains and their location in NE Puerto Rico.

The black circles represent sites sampled in 2015/2016 and circles with a dot represent sites with historical data. Different colors represent differences in elevation (m).

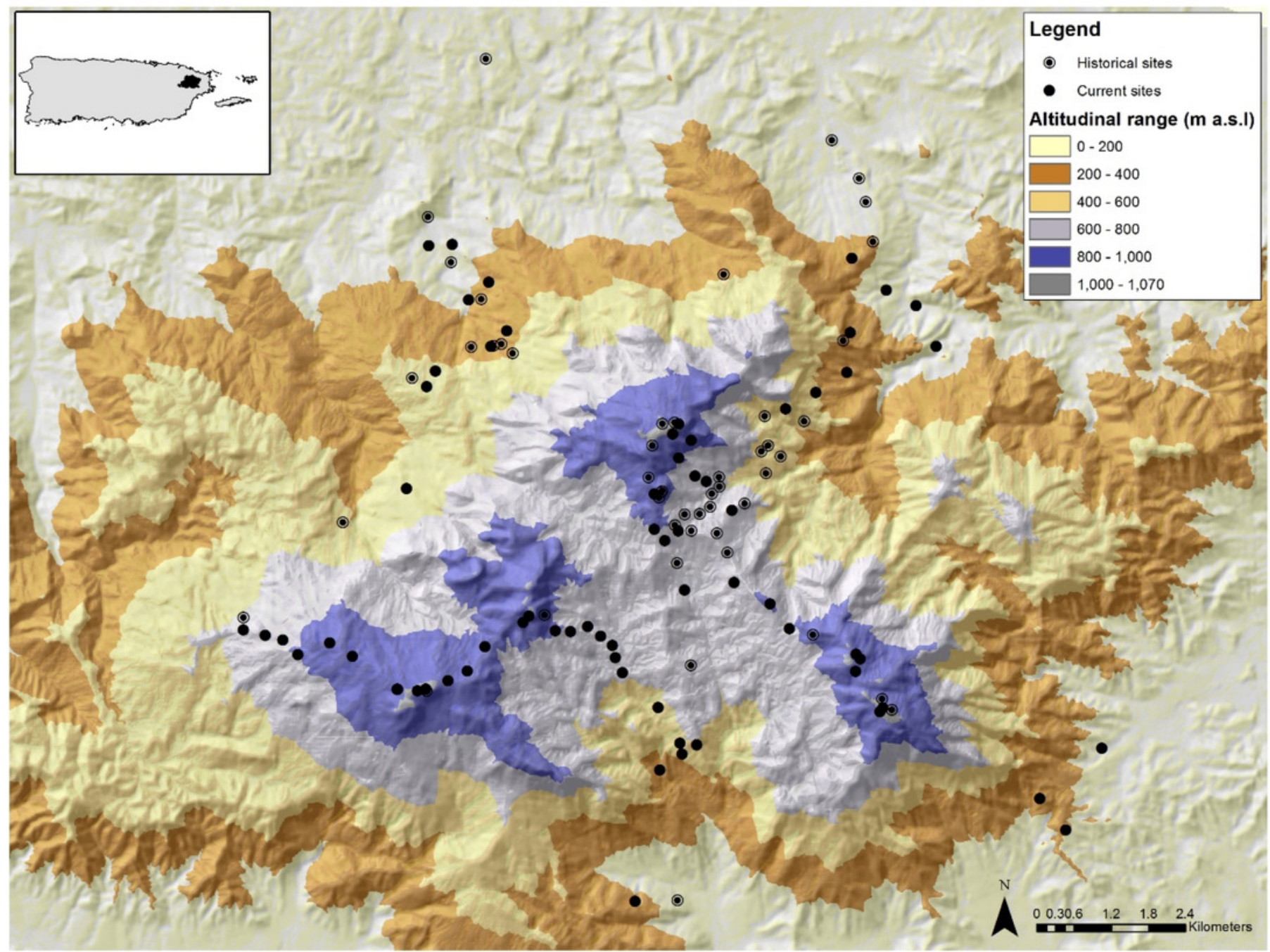


Figure 2

Comparison of raw data on species presence along the elevation gradient for 14 frog species in the Luquillo Mountains, Puerto Rico.

Open circles represent positive detections from historical data and black circles represent positive detections from current data.

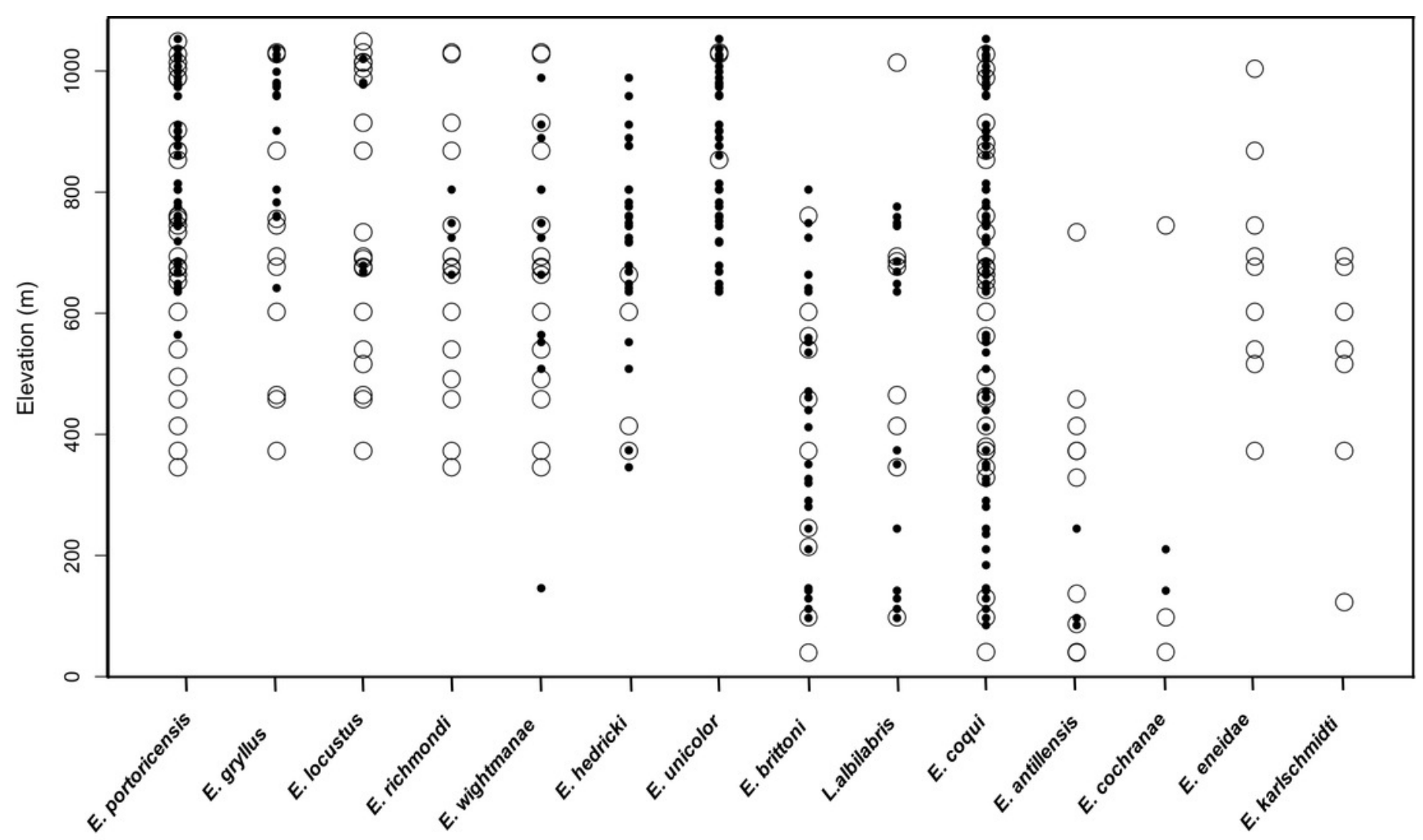


Figure 3

Historical (black line) and current (blue line) estimated elevation distributions of 11 frog species in Puerto Rico.

The observed data are show in open circles (historical) and blue circles (current). The historical and current elevation profiles were estimated by model-averaging all models with $\triangle \mathrm{AIC}<2.0$. The grey and blue shaded area represent the $95 \%$ confidence intervals. Data for the two extinct species (E. eneidae and E. karlschmidti) and E. coqui, which occur at all elevations in the historical and current data, are not included.
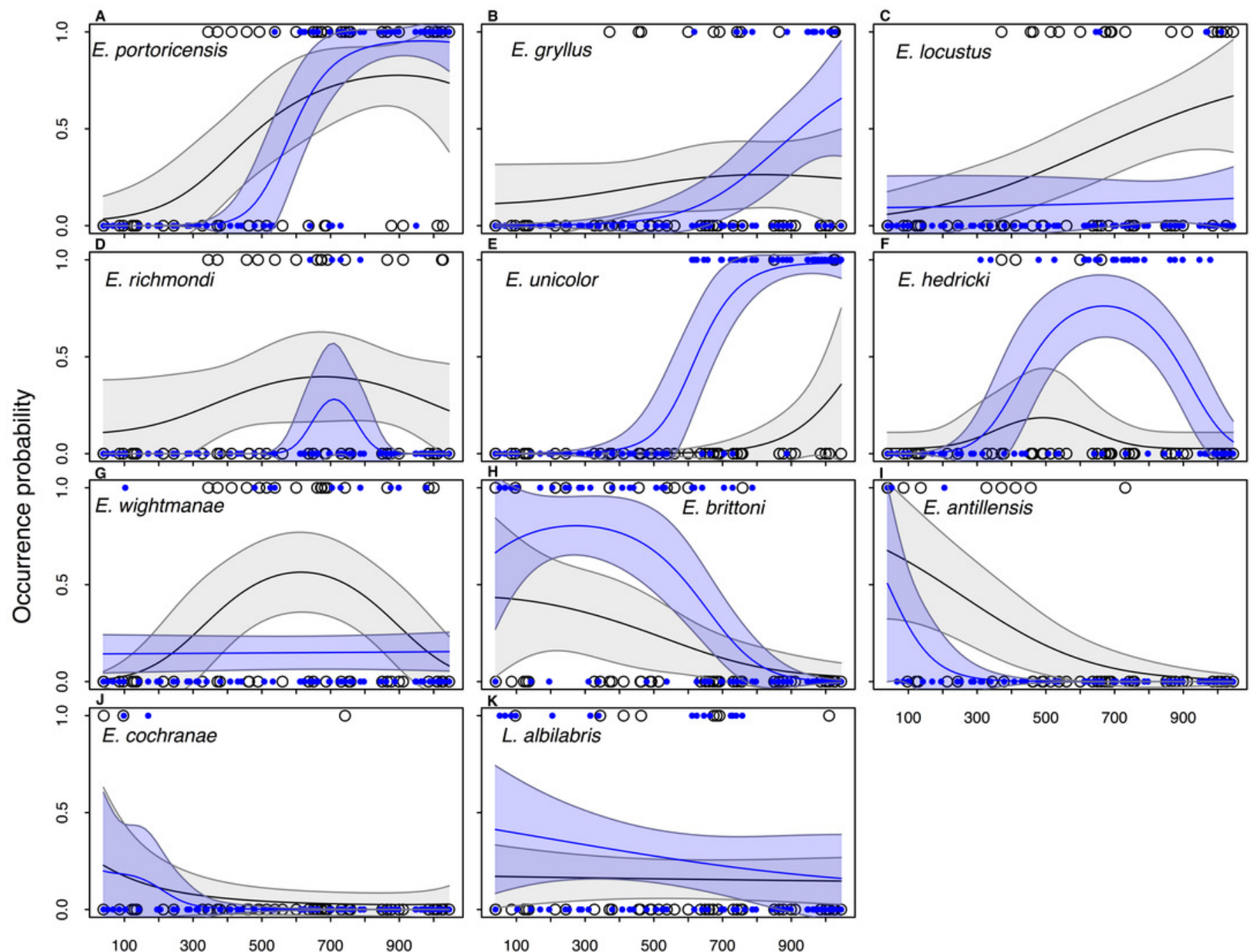

$\begin{array}{lllll}100 & 300 & 500 & 700 & 900\end{array}$

$\begin{array}{lllll}100 & 300 & 500 & 700 & 900\end{array}$

$\begin{array}{lllll}100 & 300 & 500 & 700 & 900\end{array}$

Elevation (m) 